\title{
VACUUM-ASSISTED CLOSURE OF WOUNDS- AN EFFECTIVE METHOD FOR DIABETIC ULCERS
}

\author{
Dharmendra B. L1, Vijay Kumar $N^{2}$
}

${ }_{1}^{1}$ Assistant Professor, Department of General Surgery, Mysore Medical College and Research Institute, Mysore, Karnataka, India. ${ }^{2}$ Assistant Professor, Department of Plastic Surgery, Mysore Medical College and Research Institute, Mysore, Karnataka, India.

\section{BACKGROUND}

ABSTRACT

Wounds are a major source of morbidity, lead to considerable disability and are associated with increased mortality; therefore, they have a significant impact on public health and the expenditure of healthcare resources. ${ }^{1}$ Vacuum-Assisted Closure (VAC) uses negative pressure to assist wound healing. Negative pressure drains fluid from the wound, thus removing the substrate for growth of microorganisms. Negative pressure may also accelerate granulation tissue formation and promote angiogenesis. The mechanical stimulation of cells by tensile forces may also play a role by increasing cellular proliferation and protein synthesis. Negative Pressure Wound Therapy (NPWT) involves the use of a negative pressure therapy or suction device to aspirate and remove fluids, debris and infectious materials from the wound bed to promote the formation of granulation tissue.

\section{MATERIALS AND METHODS}

A total of 50 cases clinically presenting as ulcer between January 2011 and July 2012 were taken for study. Each case was examined clinically in systematic manner as per the proforma drafted for study of all patients presenting with ulcer. VAC dressing was done, and outcome was measured by recording wound scores on days 3,7 and 10.

\section{RESULTS}

In our clinical study of 30 cases managed by VAC dressing $63.3 \%$ of the cases were of traumatic, $13.3 \%$ iatrogenic and $23.3 \%$ cases of vascular aetiology. Wound healing was better in the controlled diabetic group compared to uncontrolled diabetic group. Commonest organisms isolated were Staphylococcus, Pseudomonas and Proteus.

\section{CONCLUSION}

In our study, VAC therapy enhanced granulation tissue formation leading to better wound healing and faster recovery. VAC is thus a promising new technology in the field of wound healing with multiple applications in a variety of wounds and can be used in both acute and chronic wounds, salvage procedures or as an adjuvant therapy to improve the results of various surgical procedures.

\section{KEY WORDS}

VAC, Negative Pressure Wound Therapy, Wound Healing.

HOW TO CITE THIS ARTICLE: Dharmendra BL, Kumar VN. Vacuum-assisted closure of wounds- an effective method for diabetic ulcers. J. Evolution Med. Dent. Sci. 2018;7(36):4012-4017, DOI: 10.14260/jemds/2018/896

\section{BACKGROUND}

Vacuum-Assisted Closure (VAC) is a new technique in the challenging field of management of contaminated, acute and chronic wounds. Vacuum assisted closure (also called vacuum therapy, vacuum sealing or topical negative pressure therapy) is a sophisticated development of a standard surgical procedure, and involves the use of vacuum to remove blood or serous fluid from a wound or operation site.

Vacuum-assisted wound closure refers to wound dressing systems that continuously or intermittently apply sub-atmospheric pressure to the surface of a wound. The application of controlled levels of negative pressure has been shown to accelerate debridement and promote healing in many different types of wounds.

'Financial or Other Competing Interest': None.

Submission 27-07-2018, Peer Review 21-08-2018,

Acceptance 27-08-2018, Published 03-09-2018.

Corresponding Author:

Dr. Vijay Kumar $N$,

No. 784, Vaibava Bemal Layout

$2^{\text {nd }}$ Stage, Rajarajeswari Nagara,

Mysore-570022,

Karnataka, India

E-mail: drvijay17281@gmail.com

DOI: $10.14260 /$ jemds $/ 2018 / 896$
The optimum level of negative pressure appears to be around $125 \mathrm{mmHg}$ below ambient and it is believed that negative pressure assists with removal of interstitial fluid, decreasing localised oedema and increasing blood flow. This in turn decreases tissue bacterial levels. Despite the significant costs involved, the techniques is said to compare favourably in financial terms with conventional treatments in the management of difficult wounds. ${ }^{1}$

\section{Objectives of the Study}

To evaluate the impact of vacuum-assisted closure on wound healing in enhancing granulation tissue and wound closure in diabetic wounds.

\section{MATERIALS AND METHODS Study Design}

It is a prospective observational study. A total of 30 cases clinically presenting as diabetic ulcer between January 2016 and June 2017 admitted in all surgical units of KR Hospital attached to MMC and RI were included in the study.

\section{Inclusion Criteria}

- $\quad$ All patients with type $2 \mathrm{DM}$ and ulcers.

- $\quad$ Age group of 30 - 60 years. 


\section{Exclusion Criteria}

- Patients diagnosed as malignancies.

- Patients with venous ulcers.

Clinical examination of each case was done systematically as per the proforma drafted for the study.

\section{Sequence of Procedure}

Wound Preparation

Any dressings from the wound was removed and discarded. A culture swab for microbiology was taken before wound irrigation with normal saline. Surgical debridement was done and adequate haemostasis achieved.2,3,4,5,6

\section{Placement of Foam}

Sterile, open-cell foam dressing was gently placed into the wound cavity.

\section{Sealing with Drapes}

The site was then sealed with an adhesive drape ensuring that the drapes covered the foam and tubing and at-least three to five centimetres of surrounding healthy tissue.

\section{Application of Negative Pressure}

Controlled pressure was uniformly applied to all tissues on the inner surface of the wound using centralised vacuum pump, which could deliver either continuous of intermittent pressures ranging from 50 to $125 \mathrm{mmHg}$. The foam dressing was compressed in response to the negative pressure. ${ }^{7-19}$ The pressure was applied continuously for the first 3 days and changed as required thereafter.

The outcome was measured using wound scoring system consisting of area of wound covered with granulation tissue and its colour and consistency on each change of dressings.

\begin{tabular}{|c|c|}
\hline Granulation & Score \\
\hline None & 0 \\
\hline $1 / 4$ wound area & 1 \\
\hline $1 / 2$ wound area & 2 \\
\hline $2 / 3$ rd wound area & 3 \\
\hline \multicolumn{2}{|c|}{ Complete } \\
\hline Table 1. Wound Scoring System Format \\
\hline
\end{tabular}

\begin{tabular}{|c|c|}
\hline Colour & Score \\
\hline Pale & 0 \\
\hline Pink & 1 \\
\hline Bright Red & 2 \\
\hline
\end{tabular}

\begin{tabular}{|c|c|}
\hline Consistency & Score \\
\hline Spongy & 0 \\
\hline Solid & 1 \\
\hline
\end{tabular}

Statistical methods applied include Kruskal-Wallis test. All the statistical calculations were done through SPSS 16.0 (2007) for windows.

\section{RESULTS}

An interventional study involving 30 cases of wound was done in the Department of Surgery, KR Hospital, Mysore between January 2016 and June 2017.

\begin{tabular}{|c|r|r|c|c|}
\hline Age in Years & \multicolumn{1}{|c|}{$\mathbf{N}$} & Mean & SD & Median \\
\hline$<40$ & 11 & 5.09 & 0.94 & 5 \\
\hline $41-50$ & 15 & 4.73 & 1.22 & 5 \\
\hline$>50$ & 15 & 4.87 & 1.06 & 5 \\
\hline Total & $\mathbf{4 1}$ & $\mathbf{4 . 8 8}$ & $\mathbf{1 . 0 8}$ & $\mathbf{5}$ \\
\hline
\end{tabular}

Table 2. Age Wise evaluation of Wound Score on Day 7

Kruskal-Wallis test, $\mathrm{p}=0.8$.

Most of the patients presenting with wounds were in the $5^{\text {th }}$ decade of life 13 cases $(43.3 \%)$, followed by the $4^{\text {th }}$ decade $10(33.3 \%)$ and $<4^{\text {th }}$ decade 7 cases $(23.3 \%)$.

Wounds were more common in males 22 cases $(73.3 \%)$ than in females 8 cases $(26.7 \%)$.

Male: Female ratio was 2.75: 1.

\begin{tabular}{|c|c|c|c|}
\hline & Frequency & Percent \\
\hline \multirow{4}{*}{} & $<10$ days & 7 & 23.3 \\
\cline { 2 - 4 } & $10-30$ days & 15 & 50.0 \\
\cline { 2 - 4 } & $>30$ days & 8 & 26.7 \\
\cline { 2 - 4 } & Total & $\mathbf{3 0}$ & $\mathbf{1 0 0 . 0}$ \\
\hline \multicolumn{3}{|c|}{ Table 3. Wound Duration } \\
\hline
\end{tabular}

Based on the duration of wounds, cases were grouped into 3 categories: $<10$ days, $10-30$ days and $>30$ days. Most cases fall in the group of 10 - 30 days 15 (50\%), 7 cases $(23.3 \%)$ in the group $>10$ days and 8 cases $(26.7 \%)$ in the group of $>30$ days. ${ }^{20-30}$

Wounds were most commonly located in the foot 15 (50\%) followed by the leg 11 (36.7\%). Gluteal area, ankle, sole and abdomen 1, each $3.3 \%$. One case of wound in the abdomen was included. There was significant difference in wound healing in different location of wounds.

Based on aetiology of wounds, which were determined by history and clinical examination, wounds were divided into Traumatic, Iatrogenic and Vascular. A major portion 19 $(63.3 \%)$ of cases fell into traumatic group and $4(23.3 \%)$ into iatrogenic and 7 (23.3\%) into vascular group.

\begin{tabular}{|c|c|c|c|c|c|c|}
\hline Wound & \multicolumn{5}{|c|}{ Wound Score } & \\
\cline { 2 - 7 } Area & 3.00 & 4.00 & 5.00 & 6.00 & 7.00 & Total \\
\hline$<20 \mathrm{~cm}^{2}$ & 5 & 6 & 15 & 10 & 0 & 36 \\
\hline $21-40 \mathrm{~cm}^{2}$ & 0 & 2 & 0 & 0 & 2 & 4 \\
\hline$>40 \mathrm{~cm}^{2}$ & 0 & 1 & 0 & 0 & 0 & 1 \\
\hline Total & $\mathbf{5}$ & $\mathbf{9}$ & $\mathbf{1 5}$ & $\mathbf{1 0}$ & $\mathbf{2}$ & $\mathbf{4 1}$ \\
\hline \multicolumn{7}{|c|}{ Table 4. Wound Area- Evaluation of } \\
Wound Score on Day 7 \\
\hline
\end{tabular}

Wound area 21 - 40 sq.cm constitute maximum number of cases - 17 (56.7\%).

Wound area has an impact on wound healing. Smaller the wound area, wound healing was better compared to larger wound area.

P value- 0.001

Most common organism cultured from the wounds was Staphylococcus aureus $14 \quad(46.7 \%)$ followed by Pseudomonas and E. coli. 


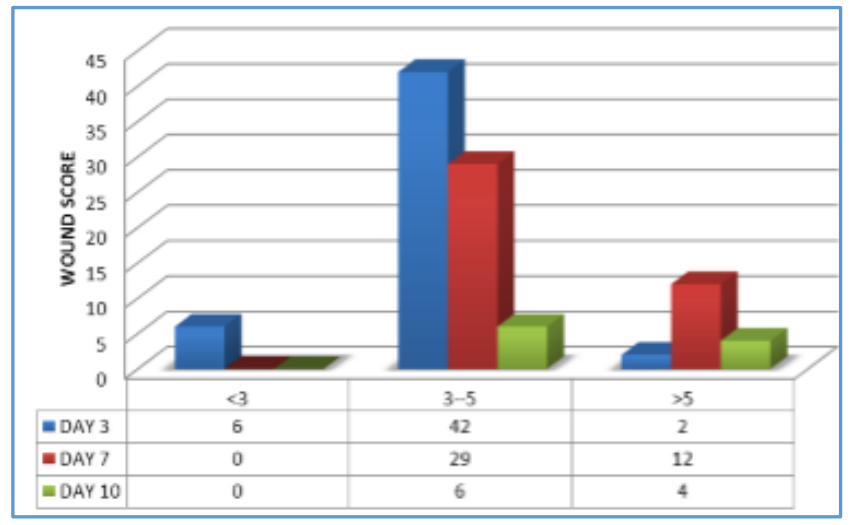

Chart 1. Wound Scores on Days 3, 7, 10

Following VAC therapy for 3 to 7 days, most of the wounds showed progress in wound healing.

Patients with blood sugar levels $<100,100-150$ showed initial good response by increased wound scoring, whereas sugar values $>150$ had no positive wound healing response.
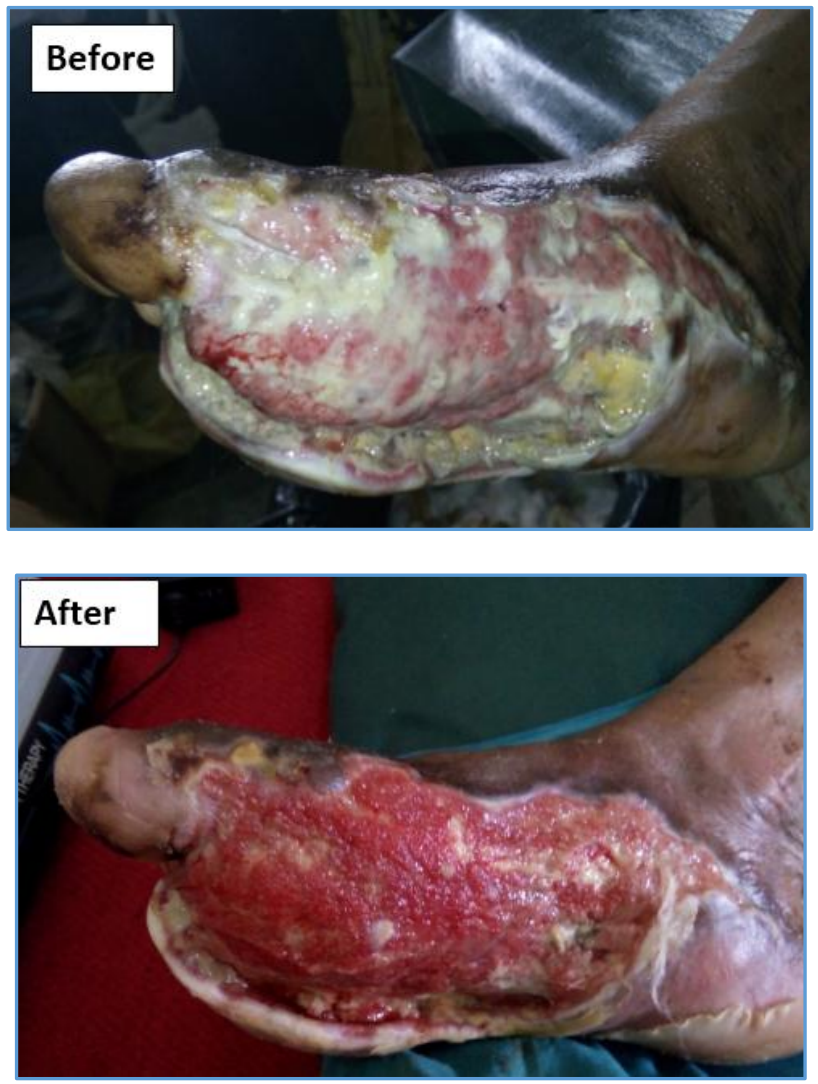

Figure 1
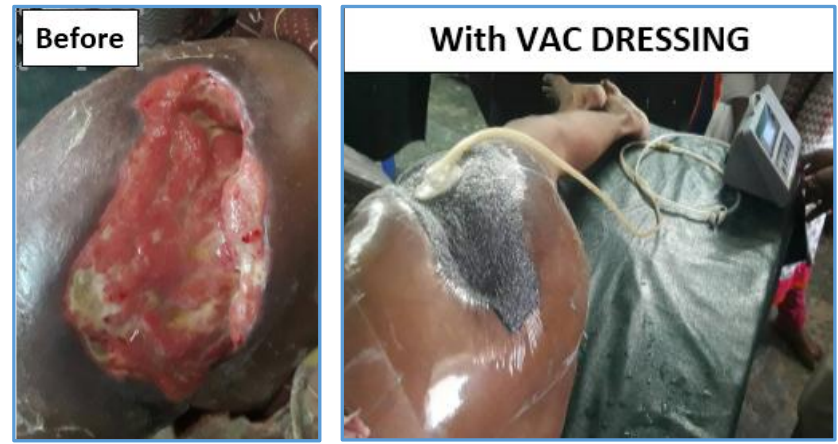

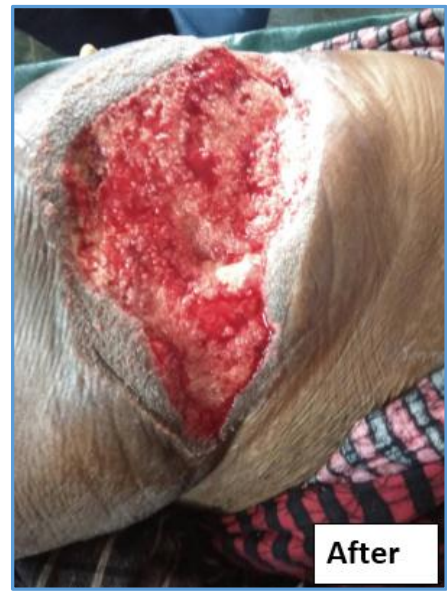

Figure 2
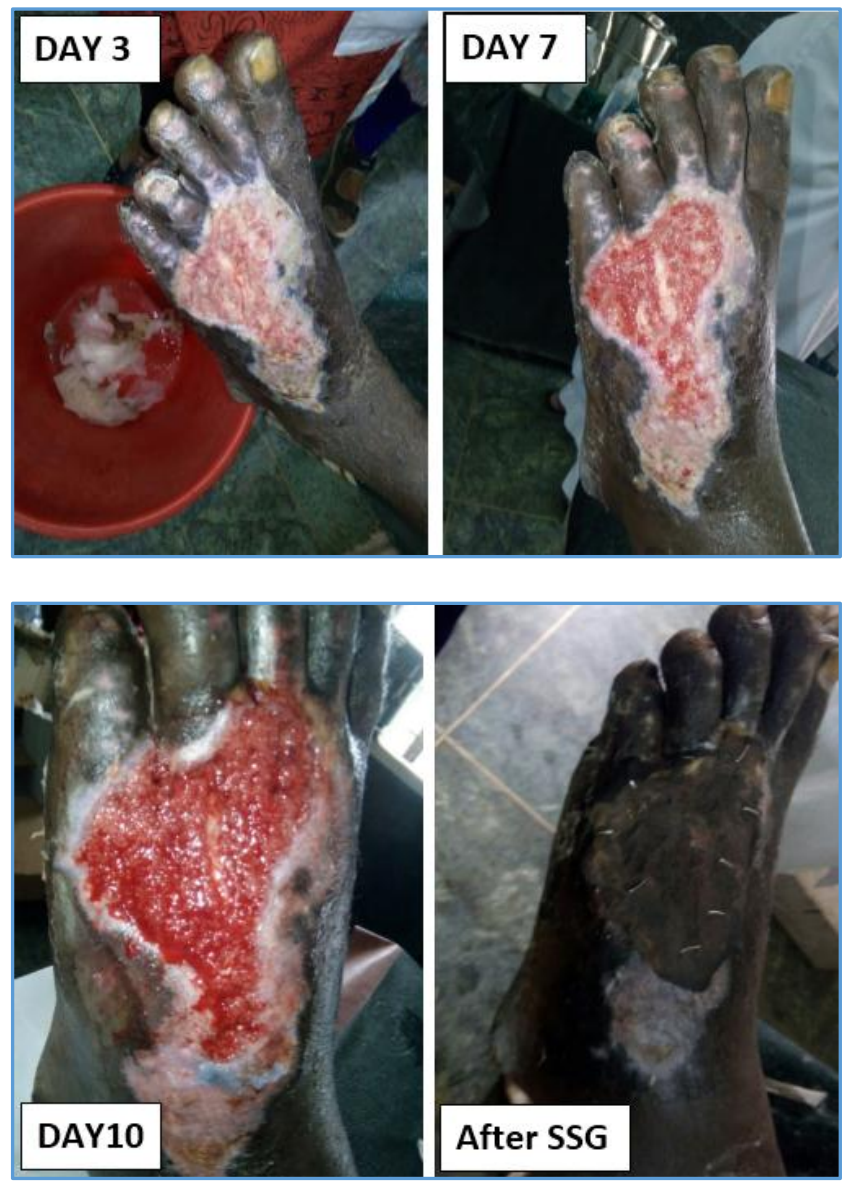

Figure 3

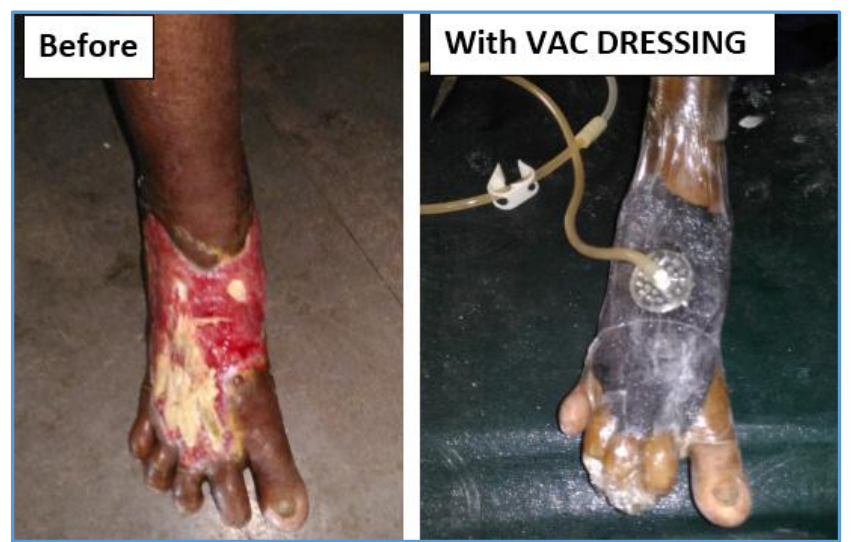




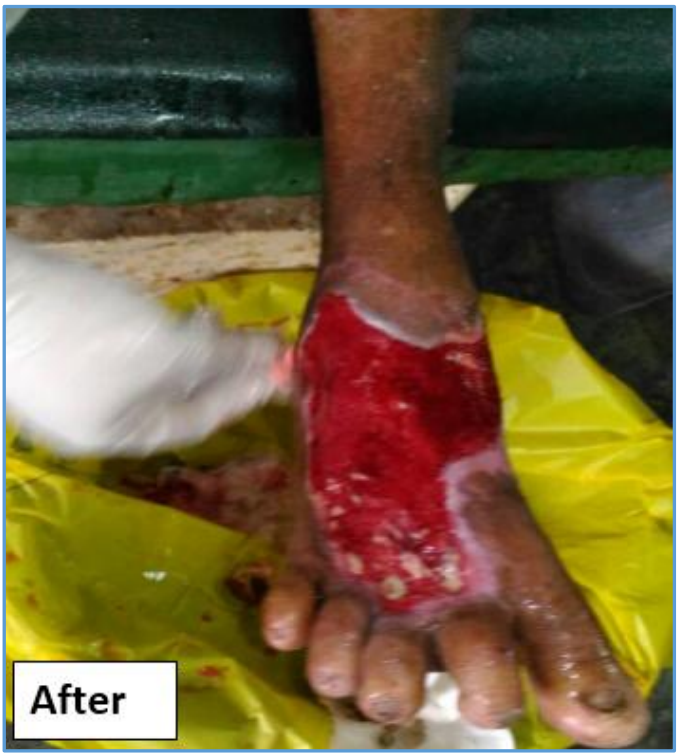

Figure 4
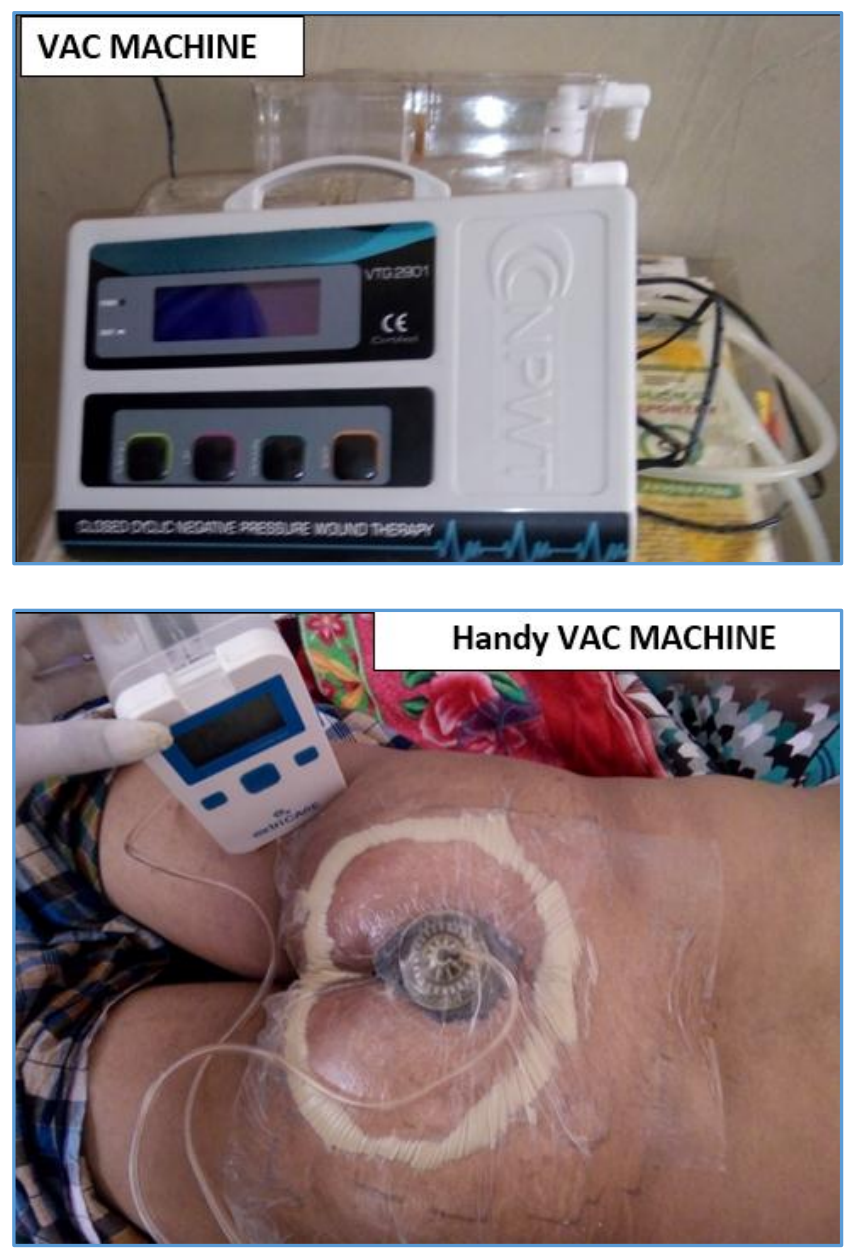

Figure 5

\section{DISCUSSION}

Delayed wound healing is a significant health problem and a challenge in the community setting, particularly in older adults with diabetes as co-morbidity. Often requires daily or more frequent hospital visits. With conventional woundhealing methods, it may take several months to heal the wound. In addition to the pain and sufferings, failure of the wound to heal also imposes social and financial burdens. Vacuum-Assisted Closure (VAC) therapy has been developed as an alternative to the standard forms of wound management, which incorporates the use of negative pressure to optimise conditions for wound healing and requires fewer painful dressing changes. ${ }^{31}$

Negative pressure therapy is an expensive treatment modality and because the costs are high, the recent consensus report suggests that use as a first-line therapy is inappropriate. However, others suggest that negative pressure therapy has the potential for saving money if it is used on the "right patients, the right wound, at the right time."

The use of negative pressure therapy has been proposed as a novel method of manipulating the chronic wound environment to assist and accelerate wound healing. Although, initial clinical results are promising, the gap between available scientific evidence and everyday clinical practice does not give a balanced view of the appropriate use of negative pressure therapy. ${ }^{32}$

Although, most studies were probably too small to detect significant difference between wounds managed by conservative dressings and by VAC, some did show VAC to result in better healing than standard methods with few serious complications. VAC appears to be a promising alternative for management of wounds. VAC was also more effective at treating various chronic and complex wounds with a significantly greater reduction in wound volume, depth and treatment's duration for VAC. It has the potential to reduce health care costs for both hospital and patients, and enhance patient satisfaction and quality of life.

Despite the early clinical success and widespread empirical introduction of VAC into clinical practice, it is not known exactly how it may exert effects on the wound. Several mechanisms have been proposed. VAC is said to increase local blood flow and reduce oedema and bacterial colonisation rates. It is thought to promote closure of the wound by promoting the rapid formation of granulation tissue as well as by mechanical and removes excess wound exudates, thus aiding in the creation of the "ideal wound healing environment."33

In our study, following VAC therapy, wound scoring was done with scores from 1 - 7 given for area of granulation tissue, colour and consistency of granulation tissue. The wounds with scores $>5$ following VAC therapy can be considered for skin graft. In the present study, > 70\% cases showed wound scores $>5$ following a week of VAC therapy.

The use of subatmospheric pressure dressings, available commercially as the VAC device, has been shown to be an effective way to accelerate healing of various wounds. The optimal subatmospheric pressure for wound healing appears to be approximately $125 \mathrm{mmHg}$. VAC has significantly increased the skin graft success rate when used as a bolster over the freshly skin-grafted wound. VAC is generally well tolerated and with few contraindications or complications is fast becoming a mainstay of current wound care. $^{34}$

$>50 \%$ of cases among diabetic wounds and $30 \%$ of cases among smokers showed scores $>5$ on day 7 of VAC therapy; thus, were showing slower healing in diabetics and smokers in spite of VAC dressings.

Diabetes mellitus is recognised as a risk factor for compromised wound healing. These data suggest that delayed healing in diabetes is associated with altered 
leukocyte infiltration and wound fluid IL-6 levels during the late inflammatory phase of wound healing. ${ }^{35}$

An increased incidence of wound complications in surgical patients with diabetes mellitus may actually reflect the increased incidence of general surgical risks or metabolic abnormalities associated with diabetes mellitus. Factors such as age, obesity, malnutrition and macrovascular and microvascular disease may contribute to wound infection and delayed wound healing, especially in the type II diabetic patient. 36

VAC dressings have certainly proven beneficial as a variant method of dressing, mainly by negative pressure therapy which sucks out serous fluid and help out in formation of granulation tissue. Used in various wounds, continuous suction for a period of $48 \mathrm{hrs}$. and later intermittent suction depending on wound status have enhanced wound healing process and faster recovery compared to conventional methods of dressing.

Diabetic wounds are always challenging; 18 cases managed by VAC therapy, 7 cases showed improvement in first 3 days of VAC therapy and of the other wounds later did not show improvement on prolonged therapy. Two cases had to undergo amputation as a result of failure of VAC therapy and other conventional methods. The main problem cited with diabetic wounds was infection, which flared up in few cases following closed VAC dressings. Hence, diabetic wounds with infections did not benefit from VAC therapy; wound debridement with control of infection, later followed by VAC dressing would be more beneficial.

Diabetic wounds, because they are traumatic and vascular benefited from VAC therapy with faster healing in terms of granulation tissue formation with controlled blood sugar values.

The study wounds also included cases of iatrogenic wounds. These showed better healing compared to other categories of wounds. There was a case of abdominal wall wound, which showed good healing following VAC therapy. There were 7 cases of vascular wounds which included ulcers associated with peripheral arterial disease.

Maintaining negative pressure in VAC dressing and the contact of the foam to the wound surface were difficult. These two issues should be taken care of for more effective usage of the VAC dressing. Other aspects to be considered are wound debridement and control of infection mainly in diabetic wounds, wherein we can delay VAC therapy until infection is controlled. In spite of the data available, reduction in the bacterial count following VAC therapy practically was more difficult when dealing with diabetic wounds.

Finally, even after considering the cost factor for VAC therapy, it is definitely a promising modality of dressing and proven beneficial in different varieties of diabetic wounds and enhances wound healing and faster recovery. ${ }^{37}$

\section{CONCLUSION}

VAC therapy is a recent modality of treatment of wounds. Its introduction has changed the course of management of wounds. Based on the data from the present study and other studies available, VAC does appear to result in better healing with few serious complications and thus looks to be a promising alternative for the management of various wounds. The application of VAC is simple, but requires training to ensure appropriate and competent use. The cost of VAC will vary and depend on the length of hospital stay and cost of supplies. There is paucity of high quality RCTs on VAC therapy for wound management with sufficient sample size and adequate power to detect differences if any between VAC and standard dressings. More rigorous studies with larger sample sizes assessing the use and costeffectiveness of VAC therapy on different wound types are required. Awareness about VAC and training on application of VAC dressings will allow its utilisation more often.

\section{REFERENCES}

[1] Eginton MT, Brown KR, Seabrook GR, et al. A prospective randomized evaluation of negativepressure wound dressings for diabetic foot wounds. Ann Vasc Surg 2003;17(6):645-9.

[2] Banwell PE, Teotl L. Topical Negative Pressure (TNP): the evolution of a novel wound therapy. J Wound Care 2003;12(1):22-8.

[3] Morykwas MJ, Argenta LC, Shelton-Brown EI, et al. Vacuum-assisted closure: a new method for wound control and treatment: animal studies and basic foundation. Ann Plast Surg 1997;38(6):553-62.

[4] Leong M, Phillips LG. Wound healing. In: Townsend CM, Beauchamp RD, Evers BM, et al. eds. Sabiston Textbook of Surgery. 19th edn. Philadelpia: Elsevier 2012: p. 151-77.

[5] Barbul A, Efron DT. Wound healing. In: Brunicardi FC, edr. Schwartz Principles of surgery. $9^{\text {th }}$ edn. New York: McGraw-Hill 2010: p. 209-33.

[6] Galiano RD, Mustoe TA. Wound Healing. In: Mulholland, Michael W, Lillemoe, et al. eds. Greenfield's Surgery: scientific principles and practice. $4^{\text {th }}$ edn. Philadelpihia: Lippincott Williams \& Wilkins 2006.

[7] Armstrong DG, Lavery LA, Fryberg RG, et al. VAC therapy appears to heal complex DRU. Abstract presented at the $2^{\text {nd }}$ World Union of Wound Healing Societies' Meeting, July 8-13, Paris, France: 2004.

[8] Lazarus GS, Cooper DM, Kinghton DR, et al. Definitions and guidelines for assessment of wounds and evaluation of healing. Arch Dermatol 1994;130(4):489-93.

[9] Joseph E, Hamori CA, Bergman S, et al. A prospective randomizes trial of vacuum-assisted closure versus standard therapy of chronic non-healing wounds. Wounds 2000;12(3):60-7.

[10] Lionelli GT, Lawrence WT. Wound dressings. Surg Clin North Am 2003;83(3):617-38.

[11] Bowler PG. Wound pathophysiology, infection and therapeutic options. Annals of Medicine 2002;34(6):419-27.

[12] Earley J. Wounds, tissue repair and scars. In: Williams NS, edr. Bailey and love's Short textbook of surgery. $25^{\text {th }}$ edn. 2010;3:29.

[13] Vacuum therapy in wound management. Vaccum Therapy. Last updated 2001. http://www.vacuumtherapy.co.uk/woundcare.htm Accessed June 2003. 
[14] Lee HJ, Kim JW, Oh CW, et al. Negative pressure wound therapy for soft tissue injuries around the foot and ankle. Journal of Orthopaedic Surgery and Research 2009;4:14.

[15] Argenta LC, Morykwas MJ. Vacuum-assisted closure: a new method for wound control and treatment: clinical experience. Ann Plast Surg 1997;38(6):563-76.

[16] Pories WJ, Schear EW, Jordan DR, et al. The measurement of human wound healing. Surgery 1966;59(5):821-4.

[17] Levin LS. The reconstructive ladder. An orthoplastic approach. Orthop Clin North Am 1993;24(3):393-409.

[18] Erba P, Ogawa R, Ackermann M, et al. Angiogenesis in wounds treated by microdeformational wound therapy. Ann Surg 2011;253(2):402-9.

[19] Ichioka S, Shibata M, Kosaki K, et al. Effects of shear stress on wound-healing angiogenesis in the rabbit ear chamber. J Surg Res 1997;72(1):29-35.

[20] Curtis ASG, Seehar GM. The control of cell division by tension or diffusion. Nature 1978;274:52-3.

[21] Brunette DM. Mechanical stretching increases the number of epithelial cells synthesizing DNA in culture. J Cell Sci 1984;69:35-45.

[22] Fabian TS, Kaufman HJ, Lett ED, et al. The evaluation of sub-atmospheric pressure and hyperbaric oxygen in ischemic full-thickness wound healing. Am Surg 2000;66(12):1136-43.

[23] Joseph E, Hamori CA, Bergman SB, et al. A prospective randomized trial of vacuum-assisted closure versus standard therapy of chronic non-healing wounds. Wounds 2000;12(3):60-7.

[24] Fleischmann W, Becker U, Bischoff M, et al. Vacuum sealing: indications technique and results. Eur J Orthop \& Traumatol 1995;5(1):37-40.

[25] Mullner T, Mrkonjic L, Kwasny O, et al. The use of negative pressure to promote the healing of tissue defects: a clinical trial using the vacuum sealing technique. Br J Plast Surg 1997;50(3):194-9.

[26] Giovanni UM, Demaria RG, Otman S. Treatment of post sternotomy wounds with negative pressure. Plast Reconstr Surg 2002;109:1747.
[27] Morykwas MJ, David LR, Schneider AM, et al. Use of subatomospheric pressure to prevent progression of partial-thickness burns in a swine model. J Burn Care Rehabil 1999;20(1 Pt 1):15-21.

[28] Buttenschoen K, Fleischmann W, Haupt U, et al. The influence of vacuum assisted closure on inflammatory tissue reactions in the postoperative course of ankle fractures. Foot and Ankle Surgery 2001;7(3):165-73.

[29] Gustafsson R, Johnsson P, Algotsson L, et al. Vacuumassisted closure therapy guided by $\mathrm{C}$-reactive protein level in patients with deep sterna wound infection. J Thorac Cardiovasc Surg 2002;123(5):895-900.

[30] Flack S, Apelquist J, Keith M, et al. An economic evaluation of VAC therapy compared with wound dressings in the treatment of diabetic foot ulcers. Journal of Wound Care 2008;17(2):71-8.

[31] Lambert KV, Hayes P, McCarthy M. Vacuum assisted closure: a review of development and current applications. Eur J Vasc Endovasc Surg 2005;29(3):219-26.

[32] Nain PS, Uppal SK, Garg R, et al. Role of negative pressure wound therapy in healing of diabetic foot ulcers. J Surg Tech Case Rep 2011;3(1):17-22.

[33] Broussard CL, Mendez-Eastman S, Franz R. Adjuvant wound therapies. In: Bryant R, edr. Acute and chronic wounds. St. Louis: Mosby 2000: p. 440.

[34] Winter GD. Formation of the scab and the rate of epithelization of superficial wounds in the skin of the young domestic pig. Nature 1962;193:293-4.

[35] Venturi ML, Attinger CE, Mesbahi AN, et al. Mechanisms and clinical applications of the VacuumAssisted Closure (VAC) Device: a review. Am J Clin Dermatol 2005;6(3):185-94.

[36] Silverstein P. Smoking and wound healing. Am J Med 1992;93(1A):22S-4S.

[37] Fahey TJ 3rd, Sadaty ABS, Jones WG 2nd, et al. Diabetes impairs the late inflammatory response to wound healing. J Surg Res 1991;50(4):308-13. 